\title{
Determinant Factors of House Price Using Regression Analysis
}

\author{
Zeni Rusmawati ${ }^{1}$, Rieska Maharani ${ }^{2}$, Dedy Surahman ${ }^{3}$ \\ \{u_zeni@yahoo.co.id ${ }^{1}$, rieskamaharani@gmail.com², dedysurahman729@gmail.com ${ }^{3\}}$ \\ Muhammadiyah University of Surabaya ${ }^{123}$
}

\begin{abstract}
House Investing is everyone desire, it is ether used for dwelling or business activities. The purpose of this study was to determine the house price (utilities, electrical, land area (LSF), building area (BSF), bedroom, bathroom, security, certificate, flood area, material, carport, facilities, and the numbers of floors). This research used the sample of 100 houses in Surabaya and Gresik. Based on regression test, the result showed that the determinant factors of the house price in Surabaya are LSF (land area), BSF (building area), bedroom and bathroom, while electrical, LSF (land area), BSF (building area), material and carport are the determinant factors in Gresik.
\end{abstract}

Keywords: House price, LSF (land area), BSF (building area), bedroom, bathroom, electrical, material, carport, Regression, Surabaya, Gresik

\section{Introduction}

The house is one of the basic human needs instead of clothing and food [1]. As population growth continues to increase, the needs for housing also increased [2]. This creates the opportunity for business to provide products in form of land or building which is called the property business. The development of economic and business activity of housing, has been the focus of many researches [3]. For many households, the house occupied by the owner are not only offer an alternative place to stay, but also part of the assets [4] consequencly, the house values have an impact on household consumption and opportunities for investment [5].

Real estate appraisal is required to provide a quantitative measurement of the benefits and obligations which arise from the ownership of real estate. We need assessments, and it is oftenly done, by a number of different players in the market such as real estate agents, lenders, brokers, developers, investors, lenders, market researchers, analysts and consultants [4]

Basically, housing prices vary based on the city and the transaction period [6]. The change of house prices has been an individuals and the government concern because the changes affect the economic and social conditions and have further impact on the national economy. Capital gains expectations of housing investment will affect the price of housing by increasing the demand for housing in turn, it will lead to the high volatility of the house price. This leads to an increase in housing prices because the supply of housing cannot adjust in the short term. The market price of the house may be affected by macroeconomic variables, spatial differences, structural characteristics of the community, and environmental facilities [7].

The selling price of the house is not only determined by the developer but buyers also participated in the prices determination. Developers determine the selling house price which is 
influenced by several factors related to the cost of houses construction such as land area, cost of construction and others. From the consumer, selling prices part is influenced by several factors such as the availability of facilities, environmental conditions, building, etc [5]

Based on it, the study will analyze which factors that influence in determining of the house selling price. Factors which affect the house price could be raised by using hedonic price method and analyzed using linear regression. This study focused on two cities in East Java, Surabaya and Gresik. Both areas have a high demand for houses compared to other regions. Both, the city has a business center, industry and education. It encourages the developers to invest to two cities.

\section{Literature Review}

The results of this research which was conducted by Sibel Selim (2008) revealed that the water systems, facilities, type of house, number of rooms, size of house, site characteristics and types of buildings are the most significant variables that affect the house price [5].

Victor Contreras, Urbi Garay, Miguel Angel Santos and Cosme (2013) investigated the relationship between factors which influence the price of land per $\mathrm{m} 2$ in the city of Caracas, Venezuela. Examined factors included land area, the amount of space for parking, the age of the building and the crime rate was going on. Researchers used hedonic price method in the determination of the factors used. These factors were then analyzed using the OLS method.

Y.W. Fung, W.L. Lee (2014) examined the factors that affect housing prices. Based on many methods used in the price determination, the correct method for this study is using hedonic price method. Factors to be examined is divided into two attributes, namely regarding architecture and the environment. The attribute architecture consists of the land area, the direction toward the window of the house (north, east, south) and for environmental attributes, it consists of distance from the house to the highway, a large angle of light and ventilation.

Y.W. Fung, W.L. Lee (2014) examined the factors that affect housing prices. Many methods used in determining the price. The correct method for this study is it uses hedonic price method. Factors to be examined is divided into two attributes, namely regarding architecture and the environment. To attribute architecture consists of the land area, the direction toward the window of the house (north, east, south) and for environmental attributes consist of distance from the house to the highway, a large angle of light and ventilation.

\section{Method}

Data collection was conducted online through www.olx.com to seek information on the selling price of houses in the Surabaya and Gresik. Each city obtained 50 data selling price of houses that will be processed using multiple linear regression analysis. In addition to the sale price of the house, other data obtained and used as independent variables, utilities, electrical, land area (LSF), building (BSF), bedroom, bathroom, security, certificate, flood area, material, carport, facilities, and number of floors.

\subsection{Empirical analysis and findings}

a. Results and Analysis Determinants of House Prices in Surabaya 
Before performing regression analysis, normality test is done firstly. By using AndersonDarling normality test p-value obtained at 0.354 or greater than 0.05 (normal data). Normality test can be seen in the following figure:

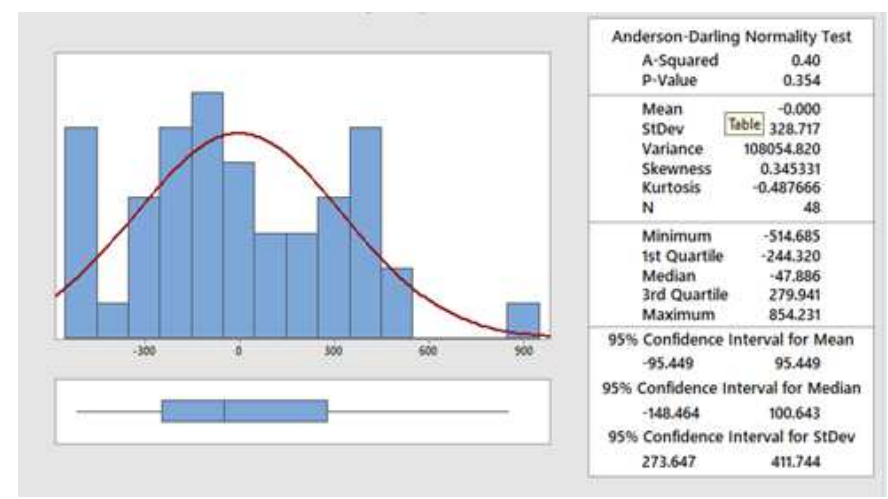

Source: Processed results of primary data (2019)

Fig.1. Normality Test

Table 1. Multicollinierity test

\begin{tabular}{lrrrrrr}
\hline & SP & Electrical & LSF & BSF & Bedroom & Bathroom \\
\hline Electrical & 0.033 & & & & & \\
& 0.619 & & & & & \\
LSF & 0.823 & 0.195 & & & & \\
BSF & 0.000 & 0.167 & & & & \\
& 0.628 & 0.240 & 0.687 & & & \\
Bedroom & 0.000 & 0.086 & 0.000 & & & \\
& 0.401 & 0.528 & 0.645 & 0.607 & & \\
Bathroom & 0.003 & 0.000 & 0.000 & 0.000 & & \\
& 0.494 & -0.053 & 0.501 & 0.531 & 0.613 & \\
Floor & 0.000 & 0.707 & 0.000 & 0.000 & 0.000 & \\
& 0.291 & 0.054 & 0.393 & 0.387 & 0.368 & 0.416 \\
& 0.036 & 0.702 & 0.004 & 0.005 & 0.007 & 0.002 \\
\hline
\end{tabular}

Source: Processed results of primary data (2019)

Multicollinierity test results showed the correlation between variables $<0.7$. This means that there is no multicollinearity between independent variables, so that all independent variables in this study can be used for further testing. After normality and multicollinearity test, then this research had regression analysis. The variables used in the regression test is the selling price of the house, utilities, electrical, land area (LSF), building (BSF), bedroom, bathroom, security, certificate, flood area, material, carport, facilities, and number of floors. However, after processing the data, it is obtained the influential variable for Surabaya. It is as follows:

Table 2. Regression Test (Surabaya)

\begin{tabular}{lrrrrr}
\hline Term & Coef & SE Coef & T-Value & P-Value & VIF \\
\hline Constant & -255 & 193 & -1.32 & 0.193 & \\
LSF & 9.54 & 1.52 & 6.26 & $0.000^{* * *}$ & 2.37 \\
\hline
\end{tabular}




\begin{tabular}{lrrrrr}
\hline BSF & 7.58 & 1.23 & 6.16 & $0.000^{* * *}$ & 2.70 \\
Bedroom & -302.8 & 86.4 & -3.51 & $0.001 * * *$ & 3.18 \\
Bathroom & 284.4 & 72.8 & 3.91 & $0.000^{* * *}$ & 2.44 \\
\hline \multicolumn{7}{c}{$* *$ Significant at the $1 \%$ level }
\end{tabular}

Source: Processed results of primary data (2019)

\section{Selling Price $=-255+$ 9,54 LSF + 7,58 BSF - 302,8 Bedroom + 284,4 Bathroom (1)}

Based on the table above, it shows that LSF (land area) positively effect on the sale price of the house. It is seen from the coefficient value of 9.54 or significant at the $1 \%$ level. The broader the land owned by the higher price of a house in Surabaya, the price of the house in Gresik is higher. Variable BSF (building) is also positively influence on the selling price. It is seen from the coefficient value of 754 significant at the $1 \%$ level. The more spacious building a house then the selling price of houses is also more expensive [5]

While the bedroom variables, based on the table above, it shows a negative influence on the selling price of the house. It is seen from the coefficient value of -302.8 significant at the $1 \%$ level. The more bathrooms owned the house, the lower the selling price of houses. These results are consistently conducted by Kurniawan,[1]. This result is suitable with the research done by [8] [5] [1]. These results prove that the decision to buy a house in Surabaya is not used for residence, but used for office or industrial. So the more the number of rooms, it is more affordable house prices. Investors who buy houses want to design their own houses which they are purchased by providing partitions which is suitable with their needs and passion ([9]. Variable number of bathroom positively effect on the sale price of the house. It is seen from the coefficient value of 284.4 significantly at the $1 \%$ level. It can be concluded that the greater number of bathrooms possessed the higher the selling price of houses in Surabaya. Since everyone wants to live cleanly [11] [12].

\subsection{Results and Analysis Determinants of House Prices in Gresik}

The data for Gresik also similar with the data from Surabaya.it has the normality test data. Normality test results can be seen in the table below:

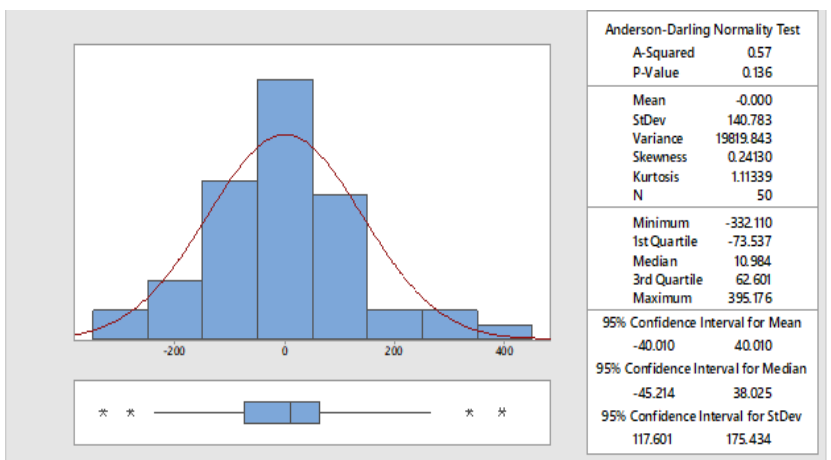

Source: Processed results of primary data (2019)

Fig. 2. Normality Test

Tabel 3. Multicollinierity test

\begin{tabular}{cccccc}
\hline & Sale price & Electrical & Surface Area & Building Area & Bedroom \\
\hline Electrical & 0.641 & & & & \\
\hline
\end{tabular}




\begin{tabular}{|c|c|c|c|c|c|}
\hline & 0.000 & & & & \\
\hline Surface Area & $\begin{array}{l}0.611 \\
0.000\end{array}$ & $\begin{array}{l}0.506 \\
0.000\end{array}$ & & & \\
\hline Building Area & $\begin{array}{l}0.656 \\
0.000\end{array}$ & $\begin{array}{l}0.680 \\
0.000\end{array}$ & $\begin{array}{l}0.654 \\
0.000\end{array}$ & & \\
\hline Bedroom & $\begin{array}{c}-0.216 \\
0.132\end{array}$ & $\begin{array}{c}-0.196 \\
0.172\end{array}$ & $\begin{array}{c}-0.394 \\
0.005\end{array}$ & $\begin{array}{c}-0.260 \\
0.069\end{array}$ & \\
\hline Bathroom & $\begin{array}{c}-0.099 \\
0.493\end{array}$ & $\begin{array}{c}-0.037 \\
0.800\end{array}$ & $\begin{array}{c}-0.308 \\
0.029\end{array}$ & $\begin{array}{c}-0.204 \\
0.155\end{array}$ & $\begin{array}{l}0.516 \\
0.000\end{array}$ \\
\hline Floor & $\begin{array}{l}0.417 \\
0.003\end{array}$ & $\begin{array}{l}0.376 \\
0.007\end{array}$ & $\begin{array}{l}0.312 \\
0.027\end{array}$ & $\begin{array}{l}0.356 \\
0.011\end{array}$ & $\begin{array}{l}0.432 \\
0.002\end{array}$ \\
\hline & & Floor & $\begin{array}{r}\text { hroom } \\
0.524 \\
0.000\end{array}$ & & \\
\hline
\end{tabular}

Multicollinierity test results showed the correlation between variables $<0.7$. This means that there is no multicollinearity between independent variables, so that all independent variables in this study can be used for further testing.

After normality test then Gresik has also regression analysis. Similar with Surabaya, the variables used in the regression is the selling price of the house, utilities, electrical, land area (LSF), building (BSF), bedroom, bathroom, security, certificate, flood area, material, carport, facilities, and the number of floors. However, after processing the data, it is obtained the most influential variable for Gresik, it is as follows.

Table 4. Regression Test (Gresik)

\begin{tabular}{lrrrrr}
\hline Term & Coef & SE Coef & T-Value & P-Value & VIF \\
\hline Constant & -1189 & 165 & -7.22 & $0.000^{* * *}$ & \\
Electrical & 0.978 & 0.117 & 8.33 & $0.000^{* * *}$ & 4.75 \\
LSF & 1.373 & 0.549 & 2.50 & $0.016^{* *}$ & 12.86 \\
BSF & 2.266 & 0.729 & 3.11 & $0.003 * *$ & 18.95 \\
Material & 152.0 & 63.5 & 2.39 & $0.021 *$ & 1.26 \\
Carport & -101.7 & 59.0 & -1.72 & $0.092 * *$ & 1.69 \\
\hline \multicolumn{6}{c}{$* *$ Significant at the 1\% level } \\
** Signifikan at the 5\% level \\
* Significant at the 10\% level \\
Source: Processed results of primary data (2019)
\end{tabular}

\footnotetext{
Selling Price $=-1189+0,978$ Electrical + 1,373 LSF + 2,266 BSF -152 Material 101,7 Carport (2)
}

According to the table and the above equation, it shows that electrical positively effect on the sale price of the house. It is seen from the value of coefficient of 0.978 or significant at the $1 \%$ level. High-wattage increasingly owned the house prices and it is more expensive. This is because living in the era of digitalization requires a great power to meet the needs of life [11].

Based on the table above, it shows that LSF (land area) positively effect on the sale price of the house. It is seen from the coefficient value of 1.373 or significant at the $1 \%$ level. The broader the land owned, the higher price of houses in Gresik. Variable BSF (building) is also 
positively influence on the selling price. It is seen from the coefficient value of 2.266 or significant at the $1 \%$ level

The more spacious building a house then the selling price of houses is also more expensive [5]. While for variable material, based on the table and the above equation, it shows the variables material and positively effect on the sale price of the house. It is seen from the coefficient value of 152 with significant at $10 \%$ level. The better the material used to build the house, the higher the selling price of houses. there are many residential locations (Driyorejo and Menganti City) which is as the land of motion, so it is necessary to build a house using the quality materials to prevent rapid deterioration.

\subsection{Analysis Determinants of House Prices in Surabaya and Gresik}

Determinants of house prices in Surabaya is LSF (land area), BSF (building), bedroom and bathroom. While electrical, LSF (building), BSF (building), material and carport are in Gresik. Based on analysis, the determining factors which are similar between the two cities are LSF (building) and BSF (land area). These results are suitable with the research conducted by [8] [5] [1]. If the buildings and land are more spacious then house prices, it will also be more expensive.

The determinant factor that distinguishes between the two cities is material, because of the different regional conditions. Gresik are located where the land is undulating so that it necessary needs the best quality materials, while Surabaya is located in the center of the city which has the flat land condition.

\section{Conclusion}

The determinant factor that distinguishes between the two cities is material, because of the different regional conditions. Gresik are located where the land is undulating so that it necessary needs the best quality materials, while Surabaya is located in the center of the city which has the flat land condition.

\section{References}

[1] Kurniawan, Dkk. (2014). Analisis Faktor-Faktor Yang Mempengaruhi Harga Jual Rumah Di Kabupatensukoharjo Dan Karanganyar. (1997), 2-6.

[2] Kajuth, F., Knetsch, T. A., \& Pinkwart, N. (2016). Assessing House Prices In Germany : Evidence From A Regional Data Set. Https://Doi.Org/10.1108/JERER-03-2016-0017

[3] Posedel, P., \& Vizek, M. (2009). House Price Determinants In Transition And EU-15 Countries. 21(3), 327-343. Https://Doi.Org/10.1080/14631370903090640

[4] Selim, H. (2009). Determinants Of House Prices In Turkey : Hedonic Regression Versus Artificial Neural Network. Expert Systems With Applications, 36(2), 2843-2852. Https://Doi.Org/10.1016/J.Eswa.2008.01.044

[5] Sibel SELIM. (2008). Determinants Of House Prices In Turkey: A Hedonic Regression Model. 9(1), 65-76.

[6] Tan, F., Cheng, C., \& Wei, Z. (2019). Modeling And Elucidation Of Housing Price. Data Mining And Knowledge Discovery, 33(3), 636-662. Https://Doi.Org/10.1007/S10618-018-00612-0

[7] Wen, H. Z., Jia, S. H., \& Guo, X. Y. (2005). Hedonic Price Analysis Of Urban Housing: An Empirical Research On Hangzhou, China. Journal Of Zhejiang University. Science, 6A(8), 907- 
914.

[8] Gautier, P. A., \& Vuuren, A. Van. (2019). The Effect Of Land Lease On House Prices is. Journal Of Housing Economics, 46(April), 101646. Https://Doi.Org/10.1016/J.Jhe.2019.101646

[9] Matongela, A. M. (2015). A Quantitative Investigation Into Determinants Of House Prices In Namibia. 6(4), 1-7.

[10] Contreras, V., Garay, U., Santos, M.A., Betancourt, C. (2014). Expropriation Risk And Housing Prices: Evidence From An Emerging Market, Journal Of Business Research 67 (2014) 935-942

[11] Eban, A. (2011). Determinants Of House Prices In Istanbul: A Quantile. (1), 305-317. Https://Doi.Org/10.1007/S11135-009-9296-X

[12] Worku, G. B. (2017). House Price Drivers In Dubai : Nonlinearity And Heterogeneity. 10(3), 384 409. Https://Doi.Org/10.1108/IJHMA-06-2016-0048

[13] Walpoel, R.E. Dan Myers R.H.(1995). Ilmu Peluang Dan Statistika Untuk Insinyur Dan Ilmuan. Bandung: ITB.

[14] Wen, H. Z., Jia, S. H., \& Guo, X. Y. (2005). Hedonic Price Analysis Of Urban Housing: An Empirical Research On Hangzhou, China. Journal Of Zhejiang University. Science, 6A(8), 907 914.

[15] Y.W. Fung, W.L. Lee, (2014). Development Of Price Models For Architectural And Environmental Quality For Residential Developments In Hong Kong, Habitat International. 44 (2014) 186e193 